\title{
TECHNOLOGICAL ENTREPRENEURSHIP OF SMALL AND MEDIUM BUSINESS IN THE REPUBLIC OF BULGARIA AS A FACTOR FOR SUSTAINABLE DEVELOPMENT
}

\author{
Angel Mirchev, Vesela Dicheva, Technical University of Varna, amirchev@cmpconsult.com, \\ vdicheva77@gmail.com
}

In the context of deepening economic and social crisis the importance of small and medium enterprises in the Republic of Bulgaria is steadily increasing. They have provided significant number of jobs on the labour market and have created much of the gross domestic product of Bulgaria. Our thesis is that technological entrepreneurship is a factor for the sustainable development of small and medium business in the country as a whole and stimulates overcoming the crisis in the country. This research paper reviews the results of a study of the conceptual apparatus of technological entrepreneurship. Based on the results, the relationship of technological entrepreneurship with sustainable development of Small and Medium Enterprises in Bulgaria is determined. The author's conclusions and definition of technological entrepreneurship as a factor for sustainable development are made on the basis of the analysis of the development of Small and Medium Enterprises in key sectors of Bulgarian economy such as tourism, power engineering, transport and industry. An attempt has been made for taking defining measures for development stimulating the technological entrepreneurship in these sectors of the national economy.

JEL Classification Number: Q010, DOI: 10.12955/cbup.2013.19

Keywords: technological entrepreneurship, sustainable development, small \& medium enterprises

\section{Introduction}

Technological entrepreneurship is a relatively new and unknown method of development and a tool for enhancement of the competitiveness of small and medium-sized industrial enterprises in Bulgaria. Its importance as a factor for sustainable development for the Bulgarian business has not been studied so far. Therefore, the purpose of this paper is to research the evolution of technological entrepreneurship in both scientific and applied aspect and its implementation in small and medium business in the country as a factor for sustainable development of the Bulgarian economy in crisis.

To achieve this aim, some research tasks are solved as follows: research development of technological entrepreneurship and holding out its role and importance as a factor for sustainable development of small and medium-sized industrial enterprises; analysis and assessment of the status and progress in different sectors which are related to technology and their relationship to sustainable development of the Republic of Bulgaria. On this basis, measures are proposed for the development of technological entrepreneurship in small and medium enterprises of the studied sectors in the economy. 


\section{Essence of technological entrepreneurship}

The first authors who studied entrepreneurship and technical entrepreneurs are Wainer and Roberts (1966). In the far year of 1966 they have spoken about technical, not technological entrepreneurship, as we call this type of entrepreneurship nowadays. Wainer and Roberts have defined technical entrepreneurs as individuals who have the typical features of the entrepreneur but also have special features which allow them to establish technical enterprises. Over the years many scientists have supplemented and expanded this statement. For example, Evans believes that technological entrepreneurship is the "creation of a new technological enterprise" (Jones Evans, 1995). And Nicholas and Armstrong (2003) have defined it as "organization, management, and risk bearing of a technology based business “

According to Claudio Petti (2009), technology entrepreneurship is a combination between two individual concepts - technology and entrepreneurship, which lead to "recognition, discovery and even creation of entrepreneurial opportunities for technological improvements". As a definition of technology Petti (2009) assumes the definition of Burgelman that it is "the theoretical and practical knowledge, skills and artefacts that can be used to develop products and services as well as their production and delivery systems." (Burgelman et al., 2004). And as a definition of entrepreneurship, he assumes that it can be described as "the identification and exploitation of previously unexploited opportunities through the creation of new resources or the combinations of existing resources in new ways to develop and commercialize new products, move into new markets and/ or service new costumers" (Hitt et al., 2001).

Bailetti (2012) makes the widest research on definitions by different authors, and in the end he offers his own definition according to which technological entrepreneurship includes human resources with special skills, an insight into these skills and a capacity for joint research and use of scientific and technological changes in favour of the company.

In our opinion technology entrepreneurship is uniting the efforts of science and business in the discovery of new technologies or the improvement of existing ones in industrial enterprises with the purpose to enhance the quality of life of people and the satisfaction of newly originated needs.

\section{Technological entrepreneurship and sustainable development- importance and relationship}

Sustainable development "Humanity has the ability to make development sustainable to ensure that it meets the needs of the present without compromising the ability of future generations to meet their own needs" (Brundtland, 1987). In this sense economic development stimulates the new technologies which are based on knowledge and innovations enhancing the maximisation of conditions coordinated with the social and cultural laws and related to achieving sustainable development of the society. The entrepreneurial approaches make these technologies popular and accessible to the medium and small industrial enterprises. Technological entrepreneurship comprises these two sciences in the best possible way and enhances the implementation of new and better technologies in different productions" in such a way as to minimise the effects of economic activity on the environment, whenever the cost impacts fall on future generation. Should such cost burdens be unavoidably imposed on the future full compensation must be paid" (Pearce, 1993). 
From the point of view of the European Union, the goals which Horizon 2020 sets are related directly to the goals of the Europe 2020 strategy. They are aimed at the development of technologies and innovations in Europe and have the task to increase the competitiveness of the European economies and at the same time to improve the sustainable development of the countries. According to the monthly bulletin of Enterprise Europe Network - Ruse center, this strategy "will help guarantee the industrial leadership of the EU and will help Europe become a more attractive place for investments and innovations by means of significant investments in key industrial technologies and greater access to capital and support for small and medium enterprises" (Horizon 2020). This plan of Europe to unite the financing of innovations and technologies during the following years will enhance even more the development of the strategy and thus stimulate the development of "innovative and more sustainable products and processes“ (Horizon, 2012). In regards to Bulgaria, as a part of the EU, has to work on this plan and aim at its fulfillment.

According to Sen Tan "The notion of sustainable development promulgates an 'ecological' strategy for economic activities that provides real improvements in the quality of human life and at the same time conserves the vitality and diversity of the Earth" (Tan, 2004). In this sense, sustainable development enhances the development of technological entrepreneurship by turning it into a means for reaching goals.

In order to live sustainably, people need to be „in harmony with other people and with nature“ (Tan, 2004), but at the same time this way of life "not require rejecting the benefits of modern technology" (Tan, 2004). It would rather require collaboration and mutual supplementation of technologies with the sustainable way of life and the respective observation of the principles of sustainable development.

\section{Sustainable development in Bulgaria and use of technologies}

\section{Sector Tourism}

As initiatives which have already given result in the area of sustainable development, we can point out the initiative of the United Nations Industrial Development Organization (UNIDO) and the State Agency of Tourism which carried out a two-year programme for sustainable development and establishment of practices in the area of clean production which aims "to reduce the intensity of the used sources, energy and materials, to limit the generation of waste, to limit the human impact in the tourist destinations" (Centre of Social and Ecological Responsibility, 2007). This is achieved in a number of hotels in the country using a plan for implementation of clean production after the model of other European hotels, and a part of the tasks is achieved by means of ,step-by-step application of ecoefficient technologies and exchange of the resource consuming equipment". The result is obtaining a „European eco-marking - a sign for compatibility with the high European standards for ecological production and services".

\section{Sector Energy}

"The energy sector in Bulgaria is characterised by a low scientific and technological potential focused on conventional energy sources such as coal and nuclear energy" (Mancheva et al., 2012).

From the point of view of Renewable Energy Sources, so far their development is not sufficiently dynamic. According to the Friedrich Ebert Foundation, it even develops with a „slow to moderate rate, without any exceptional technological breakthroughs in regards to the different RES“ (Mancheva et 
al., 2012). According to the analysis, another problem is the lack of access to the grid by the majority of the manufacturers of wind and solar energy (Mancheva et al., 2012). As a whole, according to official data there have been issued licenses for „2017 MW for wind turbines, about $230 \mathrm{MW}$ for photovoltaic installations and $15 \mathrm{MW}$ for power stations which use biomass" (Mancheva et al., 2012) so far, which gives us grounds to be optimists for the further development of energy economy by means of RES and we believe that there is much more to be done in this sector.

The aims, which European Union is putting along these lines, are:

- improving energy efficiency by $20 \%$,

- increasing the part of renewable energy to $20 \%$ (Europe 2020, 2010).

Bulgaria's policy as a member of the EU should be in the direction of increasing the part of energy production by renewable energy sources and improving energy efficiency by technological renewal in various sectors of industry. Bulgaria can stimulate more active development of renewable energy sources in this direction and has to set up clear rules associated with these alternative sources of energy.

\section{Sector Transport}

In the period before the crisis, a great part of the vehicles were renewed and European standards were introduced to them which considerably decreased the level of the carbon emissions produced. On the other hand, the percentage of used biofuel in public transport is extremely low, and there is also a lack of adequate management and investment which has led to considerable dilution of the intensity and density of the transport infrastructure (Mancheva et al., 2012). We believe that there is a big potential for development of public transport which in developed countries practically almost completely replaces the use of personal vehicles which also contribute to the pollution of the environment. The transport sector has to continue developing in the direction of encouraging the use of biofuel and improving the infrastructures, which will revive the intensity of usage of public transport by the population.

\section{Sector Industry}

According to the analysis of the Friedrich Ebert Foundation, the technological renewal related to sustainable development and the introduction of ecological standards are extremely slow in this sector (Mancheva et al., 2012). In our opinion, it is necessary to strengthen the control over the completion of projects connected with the ecological problems of the industrial enterprises in Bulgaria and to increase their standard requirements. On the other hand, funds have to be allocated for stimulation of the renewal of the technological parks of the industrial enterprises which will bring Bulgaria closer to the desired results regarding the sustainable development.

For technologically developed industrial enterprises in Bulgaria as a main criterion we can use the data of energy consumption in this sector. According to the National Committee of Bulgaria in the World Energy Council (Sulakov, 2012), in the last 15 years there is a decrease in energy consumption by over $37 \%$ in the sector of the economy. Unfortunately, the main reason for that is considered to be the many closed inefficient industries and a small part of the contribution given to the construction of new and modern industrial enterprises. Moreover, the World economic crisis from 2008 has incurred a negative impact on the development of Bulgarian industry. According to the same source, the most developed sectors are food processing, machinery construction and non-ferrous metallurgy, and the wood industry, which are taking advantage of the export to the European market. These are the most 
competitive sectors of the Bulgarian economy and investments are being made in upgrading the technologies for higher reliability. In reference to the textile industry, which has a tradition in Bulgaria, the chemical and the printing and publishing industry - they are strongly dependent on the development and implanting of new technologies. Therefore, they have to be supported by the country through various financing programs, tax incentives and export promotion.

\section{Sector Research and Development}

From the point of view of research and development (R\&D), no sufficient funds are allocated for its stimulation in our country. According to the data of Eurostat, Bulgaria has designated only $0.6 \%$ of the Gross Domestic expenditure on R\&D in 2010, which is extremely small (Eurostat, 2011). We should not forget that Europe's goal regarding this is to provide 3\% of the GNP for R\&D until 2020 (Europa 2020, 2010). Providing sufficient means in this sector will contribute to the development of technologies and innovations and will considerably enhance the access of the Bulgarian small and medium enterprises to them. At the moment, the technological innovations are exclusively imported from other countries, which make them more expensive and less accessible to the Bulgarian small and medium business. That way will be much easier for Bulgaria to achieve sustainable development in many sectors of Bulgarian business. This will make the Bulgarian enterprises more competitive.

\section{Conclusion}

This research paper examined the development of technological entrepreneurship over the years and proved its importance as a factor for sustainable development of small and medium-sized industrial enterprises in Bulgaria. In addition, the technological entrepreneurship was defined as a combined effort of science and business in the discovery of new, more effective technologies or the improvement of existing ones in industrial enterprises, with the purpose to improve the quality of life and meet newly emerging needs. The status of different production sectors in the Republic of Bulgaria was studied and analysed and on this basis proposed measures for the development of small and medium enterprises were proposed.

The results will serve as a basis for a more thorough study of the underdeveloped sectors such as industry and R\&D and an attempt to identify specific issues which can support the development of these sectors in Bulgaria in the future.

\section{References}

Bailetti, T. (2012). Technology Entrepreneurship: Overview, Definition, and Distinctive Aspects. Retrieved March 4, 2013, from http://timreview.ca/article/520

Burgelman, R. A., Christensen, C. M. \& Wheelwright, S. C. (2004). Strategic Management of Technology and Innovation. New York, NY: McGraw Hill.

Centre of Social and Ecological Responsibility. (2007). Sustainable Development of Enterprises in Bulgaria. Retrieved January 23, 2013, from http://www.serc.bg/documents/151_Brochure_1_BG.pdf

Enterprise Europe Network-Ruse centre. (2012, September). Sustainable Development and Horizon 2020. Retrieved March 2, 2013, from http://enterprise-europe-network.smebg.net/September2012.pdf 
Eurostat. (2011). Tabl. Gross domestic expenditure on R\&D (GERD). Retrieved February 12, 2013 from http://epp.eurostat.ec.europa.eu/tgm/table.do?tab=table\&init=1\&plugin=0 \&language $=$ en $\&$ pcode $=\mathrm{t} 2020 \_20$

European Commission. (2010). Europe 2020 - Strategy for Smart, Inclusive and Sustainable Growth. Brussels, Belgium: Author. Retrieved March, 16, 2011, from http://eurlex.europa.eu/LexUriServ/LexUriServ.do?uri=COM:2010:2020:FIN:EN:PDF

Hitt, M. A., Ireland, R. D., Camp, S. M. \& Sexton, D. L. (2001). Strategic entrepreneurship: entrepreneurial strategies for wealth creation. Strategic Management Journal, 22 (special issue), 479491. doi: $10.1002 / \mathrm{smj} .196$

Jones-Evans, D. (1995). A typology of technology-based entrepreneurs: A model based on previous occupational background. International Journal of Entrepreneurial Behaviour \& Research, 1 (1), 26 47. doi: $10.1108 / 13552559510079751$

Mancheva, D., Karaboev, S. \& Stefanov, R. (2012). Green Growth and Sustainable Development: priorities for Bulgaria. Sofia, Bulgaria: Friedrich Ebert Foundation. Retrieved April 10, 2013, from http://library.fes.de/pdf-files/bueros/sofia/09016.pdf

Nicholas, S. P. \& Armstrong, N. E. (2003). Engineering Entrepreneurship: does entrepreneurship have a role in engineering education. Antennas and Propagation Magazine, IEEE, 45 (1), 134-138. doi: 10.1109/MAP.2003.1189659

Petti, C. (2009). Cases of Technological Entrepreneurship. Cheltenham, UK: Edward Elgar Publishing Inc.

Pearce, D. (1993). Blueprint 3: Measuring sustainable development. London, UK: Earthscan.

Roberts, E. \& Wainer, H. (1966). Some Characteristics of Technical Entrepreneurs. Cambridge, MA: M.I.T. Computation Center.

Sulakov, S. (2012). Forecast growth in electricity consumption in Bulgaria until 2050, taking into account demographic changes and technological improvements. Sofia, Bulgaria: World Energy Council.

Tan, S. S. (2004). Ecological Perspectives in Entrepreneurship: Science And Sustainability. Singapore: Nanyang Technological University.

World Commission on Environment and Development (WCED). (1978). The Report of the Brundtland's Commission. Oxford, UK: Oxford University Press. 